Pobrane z czasopisma Studia Iuridica Lublinensia http://studiaiuridica.umes.pl Data: 26/04/2023 17:14:00

Glosses Studia luridica Lublinensia vol. XXVIII, 2, 2019 DOI: 10.17951/sil.2019.28.2.205-213

\author{
Sławomir Zwolak \\ Uniwersytet Rzeszowski \\ OCID: 0000-0002-4075-4400 \\ sla_z@poczta.fm
}

\title{
Glosa do wyroku Naczelnego Sądu Administracyjnego z dnia 2 lipca 2018 r. (II OSK 3285/17, LEX nr 2523637)
}

Gloss to the Judgement of the Supreme Administrative Court of 2 July 2018 (II OSK 3285/17, LEX No. 2523637)

\section{STRESZCZENIE}

Naczelny Sąd Administracyjny w wyroku z dnia 2 lipca 2018 r. (II OSK 3285/17, LEX nr 2523637) przyjął, że decyzję nakazującą usunięcie stwierdzonych nieprawidłowości w obiekcie budowlanym można skierować do zarządcy tego obiektu. Według Naczelnego Sądu Administracyjnego za „zarządcę obiektu budowlanego” nie można jednak uznać osoby, która nigdy nie władała tym obiektem budowlanym i nie jest ujawniona w ewidencji gruntów i budynków jako władający.

Słowa kluczowe: właściciel; zarządca; utrzymanie i użytkowanie obiektu budowlanego

Nie sposób automatycznie przyjmować, że następcy prawni osoby wpisanej do ewidencji gruntów jako wyłącznie posiadacz nieruchomości, na skutek dziedziczenia wstąpili w jego sytuację prawną obejmującą przejęcie obowiązków wynikających z art. 61 pr. bud. Pozyskanie bowiem pewnej wiedzy o nieruchomości nie kreuje jeszcze statusu zarządcy obiektu budowlanego (art. 61 pr. bud.).

$* * *$

Wyrok został wydany w następującym stanie faktycznym. Powiatowy inspektor nadzoru budowlanego (PINB) nakazał trzem osobom fizycznym wykonanie 
w określonym terminie robót budowlanych w celu zabezpieczenia będącego w złym stanie technicznym budynku mieszkalnego. Roboty te obejmowały m.in. wzmocnienie fundamentów, uszczelnienie pęknięć ścian, przemurowanie uszkodzonego narożnika, uszczelnienie otworów okiennych. PINB uznał, że budynek znajduje się w nieodpowiednim stanie technicznym oraz może spowodować zagrożenie dla życia lub zdrowia ludzi. Ponadto stwierdził, że nakaz wykonania robót należy skierować do wspomnianych osób, ponieważ są spadkobiercami osoby w przeszłości władającej tym obiektem budowlanym.

Od decyzji PINB odwołanie złożyli adresaci tej decyzji. Wojewódzki inspektor nadzoru budowlanego (WINB) jednak utrzymał w mocy zaskarżoną decyzję. WINB uznał, że decyzja organu pierwszej instancji jest słuszna - budynek znajduje się w złym stanie technicznym, a ustalenia PINB w tym zakresie są prawidłowe. Dlatego zdaniem WINB decyzja nakazująca usunięcie stwierdzonych nieprawidłowości w obiekcie budowlanym na podstawie art. 66 ust. 1 pkt 1 i 3 ustawy z dnia 7 lipca 1994 r. - Prawo budowlane ${ }^{1}$ jest zasadna.

Na decyzję WINB jeden z jej adresatów złożył skargę do Wojewódzkiego Sądu Administracyjnego w Warszawie. Skarżący wskazał, że nigdy nie zamieszkiwał w spornym budynku i nie ponosił żadnych ciężarów publicznoprawnych z nim związanych. Ponadto nie posiada żadnego tytułu prawnego do nieruchomości, na której jest położony budynek. Działka, na której jest on zlokalizowany, nie wchodzi w skład spadku odziedziczonego przez skarżącego. Z tego powodu zdaniem skarżącego brak było podstaw do nakazu wykonania przez skarżącego jakichkolwiek robót budowlanych na przedmiotowej działce. Skarżący nie jest ani właścicielem tej nieruchomości, ani jej zarządcą, dlatego nie ma w tym przypadku zastosowania art. 66 pr. bud. WSA uwzględnił tę skargę i w konsekwencji uchylił zarówno zaskarżoną decyzję WINB, jak i poprzedzającą ją decyzję PINB. WSA wskazał, że wprawdzie ustalenia organów dotyczące stanu technicznego budynku są prawidłowe, jednak skierowanie decyzji do adresatów wskazanych w tej decyzji było przedwczesne. Zdaniem WSA adresatem decyzji opartej na art. 66 pr. bud. może być wyłącznie co do zasady właściciel lub zarządca obiektu budowlanego. Wynika to z art. 61 pr. bud. Przy czym redakcja tego przepisu wskazuje, że w pierwszej kolejności decyzję należy kierować do właściciela, a następnie do zarządcy, skoro zapewnienie właściwej eksploatacji użytkowanego obiektu budowlanego zgodnie z jego przeznaczeniem oraz jego utrzymanie w odpowiednim i bezpiecznym stanie technicznym należy do tych podmiotów. W przypadku współwłasności obiektu budowlanego obowiązek jego utrzymania w należytym stanie ciąży na wszystkich współwłaścicielach łącznie. WSA podkreślił, że w sytuacji gdy nieruchomość nie ma ustalonego właściciela ani zarządcy, funkcję tę pełni podmiot władający działką, ujawniony jako władający w ewidencji gruntów i budynków. Spadkodawca

1 T.j. Dz.U. 2018, poz. 1202 z późn. zm., dalej jako: pr. bud. 
adresatów zaskarżonej decyzji był wpisany w tej ewidencji. Jednakże zdaniem WSA nie można uznać za zarządców obiektu budowlanego w rozumieniu art. 61 pr. bud. podmiotów, które nie spełniają powyższych kryteriów. Nie mogą zatem być zarządcami obiektu budowlanego osoby, które nigdy nie władały nieruchomością i nie figurują w ewidencji gruntów i budynków jako władający. Zarządcą obiektu budowlanego nie będą więc spadkobiercy osoby, która władztwo nad obiektem faktycznie wykonywała i w ewidencji gruntów została wymieniona. WSA zwrócił uwagę, że w aktach sprawy brak jest dokumentu potwierdzającego, że adresaci decyzji (spadkobiercy władającego niegdyś nieruchomością) faktycznie władali nieruchomością. Kwestia ta w ocenie WSA wymaga dalszego zbadania przez organy².

Skargę kasacyjną od wyroku WSA do Naczelnego Sądu Administracyjnego wywiódł WINB. NSA jednak uznał, że skarga jest nieuzasadniona i ją oddalił. NSA zgodził się z sądem pierwszej instancji, że skoro osoba ujawniona w ewidencji gruntów i budynków jako posiadacz nieruchomości (władający) nie była jej właścicielem, to spadkobiercy tej osoby automatycznie, poprzez fakt spadkobrania, nie stają się posiadaczami nieruchomości ani zarządcami obiektu budowlanego na niej położonego. Tym samym skierowanie decyzji do spadkobierców byłego posiadacza nieruchomości było błędne.

Istotą problemu, jaki wyłania się na tle analizowanego wyroku NSA, jest zasadniczy spór dotyczący kwestii podmiotów, na które dopuszczalne jest nałożenie obowiązków wykonania określonych robót w obiekcie budowlanym będącym w złym stanie technicznym.

Rozpoczynając analizę przedmiotowego wyroku NSA, należy wyjaśnić zagadnienie związane z właściwymi podmiotami wynikającymi z art. 61 pr. bud. W świetle ustawy Prawo budowlane podmiotami obowiązków w fazie użytkowania obiektu budowlanego są właściciel i zarządca obiektu budowlanego. Ich celem jest utrzymanie we właściwym stanie już wybudowanego obiektu budowlanego ${ }^{3}$. Ustawodawca, wskazując expressis verbis $\mathrm{w}$ art. 61 pr. bud. zobowiązane podmioty do utrzymania i użytkowania, jednocześnie nie uregulował w czytelny sposób przesłanek ustalenia adresata decyzji, gdy chodzi o wybór pomiędzy właścicielem obiektu budowlanego i jego zarządcą. Wydaje się jednak, że kolejność wymienionych podmiotów nie jest bez znaczenia - ustawodawca w pierwszej kolejności wskazuje na właściciela, a fakt ten wynika z tego, że prawo własności jest prawem dającym najszersze władztwo nad rzeczą. Dlatego najpierw obowiązki związane z użytkowaniem obiektu budowlanego będą ciążyć na właścicielu, jak również będą skutkować domniemaniem na jego rzecz w sytuacjach wątpliwych ${ }^{4}$. Następnie

2 Wyrok WSA w Warszawie z dnia 27 czerwca 2017 r., VII SA/Wa 1895/16, LEX nr 2342718. Zob. S. Jędrzejewski, Nowe prawo budowlane, Bydgoszcz 1994, s. 70-71.

4 Należy podkreślić, że przede wszystkim na właścicielu nieruchomości ciąży obowiązek dbałości o to, aby obiekt budowlany był użytkowany w sposób zgodny z jego przeznaczeniem, niezależnie 
przejdą na zarządcę w sytuacji, gdy zostanie na podstawie umowy o zarządzanie ustanowiony zarządca nieruchomości.

Podstawową i najważniejszą osobą w sferze użytkowania obiektu budowlanego jest jego właściciel. Właścicielem obiektu budowlanego jest podmiot prawa cywilnego będący osobą fizyczną, osobą prawną, jednostką organizacyjną niebędącą osobą prawną, której ustawa przyznaje zdolność prawną (tzn. zdolność do bycia podmiotem praw i obowiązków). Właścicielowi obiektu przysługuje prawo własności względem tego obiektu, który jako podmiot zgodnie z art. 140 k.c. może w granicach określonych przez ustawy i zasady współżycia społecznego, z wyłączeniem innych osób, korzystać z obiektu budowlanego zgodnie ze społeczno-gospodarczym przeznaczeniem i w tych samych granicach może tym obiektem rozporządzać. $Z$ tego wynika, że własność nawiązuje do tradycyjnego określenia uprawnień właściciela, które obejmują: ius possidendi (uprawnienie do posiadania obiektu), ius utendi (uprawnienie do korzystania z obiektu), ius abudenti (uprawnienie do zużycia, rozbiórki obiektu), ius disponendi (uprawnienie do rozporządzania obiektem) $)^{5}$. W przypadku gdy obiekt budowlany przysługuje niepodzielnie kilku osobom, to obowiązki wynikające z użytkowania obiektu spoczywają na wszystkich współwłaścicielach. Nie można zatem obciążyć tymi obowiązkami tylko jednego ze współwłaścicieli, nawet gdy będzie ponosił winę za zaistniały stan rzeczy. Współwłasność jest rodzajem własności, nie jest więc samodzielną instytucją prawną i w związku z tym do współwłasności odnoszą się wszystkie przepisy o własności, jeżeli co innego nie wynika z charakteru współwłasności jako niepodzielnego prawa do tej samej rzeczy w zakresie korzystania ze wspólnego obiektu budowlanego ${ }^{6}$. Odnosząc się do współwłasności, istotne wydaje się ustalenie, w jakim rozmiarze własność służy poszczególnym jej właścicielom, przy czym w tej sytuacji właściwy organ nadzoru budowlanego nie kieruje się wielkością udziałów we współwłasności i wszelkie decyzje kierowane są do wszystkich współwłaścicieli obiektu budowlanego ${ }^{7}$. Funkcjonowanie wielu współwłaścicieli obiektu budowlanego, na których spoczywają obowiązki w zakresie utrzymania obiektu, może powodować sytuację, w której właściciele nie będą się wywiązywać $\mathrm{z}$ nałożonych obowiązków. $Z$ tego powodu wprowadza się równolegle dodatkowe rozwiązania zabezpieczające, które polegają na możliwości ustanowienia zarządcy przymusowego przez sąd. Natomiast jeśli pomiędzy współwłaścicielami zostanie

od tego, czy właściciel sam ten obiekt wykorzystuje czy oddał go do użytkowania innemu podmiotowi. Zob. wyrok WSA w Poznaniu z dnia 23 kwietnia 2008 r., I SA/Po 508/07, LEX nr 505941; wyrok WSA w Warszawie z dnia 1 kwietnia 2011 r., VII SA/Wa 2514/10, LEX nr 1128161.

5 L. Myczkowski, Własność budynków i lokali oraz inne prawa rzeczowe w praktyce, Warszawa 2005, s. 11.

6 S. Rudnicki, Własność nieruchomości, Warszawa 2008, s. 24.

7 Wyrok WSA w Gdańsku z dnia 13 stycznia 2011 r., II SA/Gd 733/10 LEX nr 752627; wyrok WSA w Białymstoku z dnia 8 maja 2008 r., II SA/Bk 535/07, LEX nr 510175. 
zawarta ugoda sądowa o podziale obiektu do użytkowania, wówczas właściwy organ, orzekając o obowiązku utrzymania w należytym stanie określonej części obiektu, pozostającej w wyłącznym użytkowaniu jednego ze współwłaścicieli, może kierować wydane decyzje tylko do jednego współwłaściciela ${ }^{8}$.

Drugim wskazanym przez ustawodawcę podmiotem w fazie użytkowania obiektu budowlanego jest zarządca. Pojęcie zarządcy obiektu budowlanego jest niejednoznaczne i posługują się nim liczne akty normatywne. Generalnie przyjmuje się, że w obowiązującym stanie prawnym przez zarządzanie w rozumieniu art. 61 pr. bud. należy rozumieć: trwały zarząd w rozumieniu art. 43-50 ustawy z dnia 21 sierpnia 1997 r. o gospodarce nieruchomościami ${ }^{9}$, zarząd wykonywany zgodnie z przepisami art. 184-190 u.g.n. oraz zarząd rzeczą wspólną zgodnie z art. 200-201 k.c. ${ }^{10}$ Przez pojęcie zarządu należy rozumieć całokształt czynności prawnych i faktycznych dotyczących przedmiotu. W określeniu „zarządzanie” mieści się także „administracja”, która ma jednak znacznie węższy zakres i obejmuje w zasadzie tylko czynności faktyczne. Czynności w ramach wykonywania zarządu mogą dotyczyć zarówno bieżącej eksploatacji rzeczy, jak i sytuacji szczególnych ${ }^{11}$. Zatem zarządca to podmiot, który troszczy się o utrzymanie nieruchomości w stanie niepogorszonym, a czasem także poprawia stan nieruchomości, odpowiadając za konserwację, naprawy, remonty, utrzymanie czystości i porządku ${ }^{12}$. Biorąc pod uwagę pojęcie zarządcy z art. 61 pr. bud., należy uznać, że jest to każdy podmiot, któremu przysługują uprawnienia właścicielskie zmierzające do utrzymania nieruchomości we właściwym stanie technicznym. Jak widać, prawa zarządcy opierają się na konstrukcji upoważnienia do działania w cudzej sferze prawnej, przy czym ustanowienie zarządcy upoważnia go do wykonywania uprawnień i obowiązków w zakresie własności i zarazem wyłącza taką kompetencję właściciela ${ }^{13}$. Zdarza się, że właściciele lub współwłaściciele obiektu budowlanego zarządzają swoim obiektem - pełnią oni wówczas rolę zarządcy. W tej sytuacji oczywiste staje się, że podstawą pojawienia się $\mathrm{w}$ danym obiekcie jakiegoś zarządcy, który nie jest właścicielem tego obiektu, jest umowa o zarządzanie zawarta przez tego zarządcę z właścicielem albo ze współwłaścicielami obiektu bądź z innymi osobami, które reprezentują właścicieli. Taka umowa powinna określać prawa i obowiązki stron, w tym zakres czynności, jakie ma wykonywać zarządca. Zarządcą działającym na podstawie takiej umowy może być zarówno osoba fizyczna, jak i podmiot gospodarczy (osoba fizyczna lub prawna albo jednostka organizacyjna nieposiadająca

\footnotetext{
Wyrok NSA we Wrocławiu z dnia 14 maja 1996 r., SA/Wr 2096/95, LEX nr 29541.

T.j. Dz.U. 2018, poz. 2204 z późn. zm., dalej jako: u.g.n.

10 Wyrok NSA z dnia 21 marca 2012 r., II OSK 2596/10, LEX nr 1145621.

11 B. Baran, Prawo cywilne dla zarządców nieruchomości, Warszawa 2012, s. 101.

12 E. Bończak-Kucharczyk, Zarzadzanie nieruchomościami mieszkalnymi. Aspekty prawne i organizacyjne, Warszawa 2011, s. 22.

13 Wyrok NSA z dnia 3 lutego 2011 r., II OSK 245/10, LEX nr 992523.
} 
osobowości prawnej), świadczy on bowiem usługę na rzecz właściciela lub właścicieli i każdy, kto prowadzi działalność w zakresie zarządzania obiektem, może występować $\mathrm{w}$ tej roli ${ }^{14}$. Faktyczna rola zarządcy może być różna. Zakres jego uprawnień i obowiązków jest węższy lub szerszy, w zależności od rodzaju umowy o zarządzaniu zawartej między właścicielem i zarządcą. W najbardziej ograniczonym zakresie zarządca obiektu wykonuje funkcje wykonawcze administratora budynku, ograniczone do zapewnienia właściwego użytkowania, wyłączając m.in. sprawy zmiany sposobu przeznaczenia oraz decyzje inwestycyjne polegające na przebudowie i rozbudowie obiektu budowlanego. $Z$ kolei w najszerszym zakresie zarządca wykonuje całość praw właścicielskich, powierzając mu nie tylko rozporządzanie obiektem, lecz także ochronę prawa własności i podejmowanie działań inwestycyjnych. Jedynym wyjątkiem w tej sytuacji jest prawo kontroli ze strony właściciela obiektu ${ }^{15}$.

Warto w tym miejscu zauważyć, że w świetle orzecznictwa sądowoadministracyjnego pojęcia „zarządca obiektu budowlanego”, o którym mowa w art. 61 pr. bud., nie należy utożsamiać z pojęciem „zarządca nieruchomości”. W pierwszym ze wskazanych pojęć mieści się zarówno podmiot władający całą nieruchomością, na rzecz którego ustanowiono ograniczone prawo rzeczowe, jak i podmiot, który włada nieruchomością z tytułu umowy o korzystanie z cudzej rzeczy. Pojęciem zarządcy obiektu budowlanego należy więc objąć każdą osobę (tj. użytkownika, dzierżawcę, najemcę) władającą tym obiektem na podstawie zawartego z właścicielem stosunku prawnego, na której spoczywa obowiązek zarządzania tą nieruchomością ${ }^{16}$. W sytuacji gdy nieruchomość nie ma ustalonego właściciela ani zarządcy, funkcje te pełni podmiot władający działką, wpisany jako władający w rejestrze gruntów i budynków. Zakres takiego władania odpowiada posiadaniu samoistnemu, które jest nie tylko formą władztwa nad rzeczą, a więc stanem faktycznym, lecz także zawiera czynnik psychiczny, tj. wolę posiadania. W kontekście glosowanego wyroku NSA uprawnione wydaje się stwierdzenie, że skoro podmiot wpisany do ewidencji gruntów i budynków jako władający sprawuje swoje władztwo nad rzeczą z zamiarem wykonywania tego władztwa jako właściciel, to również on będzie zobowiązany do zapewnienia prawidłowego utrzymania obiektu budowlanego. $\mathrm{Z}$ tych przyczyn w przypadku braku właściciela bądź zarządcy nieruchomości podmiot wpisany do ewidencji gruntów i budynków jako władający nieruchomością jest adresatem decyzji nakazującej usunięcie stwierdzonych naruszeń prawa, o którym mowa w art. 66 pr. bud. w zw. z art. 61 pr. bud. ${ }^{17}$ Nie można więc uznać

14 E. Bończak-Kucharczyk, op. cit., s. 23.

15 A. Śliwiński, Zarządzanie nieruchomościami. Podstawy wiedzy i praktyki gospodarowania nieruchomościami, Warszawa 2000, s. 27-28.

16 Wyrok WSA we Wrocławiu z dnia 25 lipca 2012 r., II SA/Wr 167/12, LEX nr 1229042.

17 Wyrok NSA z dnia 12 stycznia 2017 r., II OSK 976/15, LEX nr 2198117. 
za zarządcę obiektu budowlanego - w rozumieniu art. 61 pr. bud. - podmiotu, który nie spełnia wyżej wskazanych kryteriów. Chodzi tu o taką osobę, która nigdy nie władała nieruchomością i nie figurowała w rejestrze gruntów i budynków jako osoba władająca. W związku z tym zarządcą obiektu budowlanego nie będzie spadkobierca osoby, która władztwo nad obiektem faktycznie wykonywała i została wymieniona w ewidencji gruntów.

Równie problematycznym zagadnieniem jest ustalenie, czy zarządcą może być najemca lub dzierżawca, w szczególności gdy przyjął on na siebie na podstawie umowy najmu lub dzierżawy wszystkie obowiązki w zakresie utrzymania obiektu W należytym stanie technicznym oraz $\mathrm{w}$ zakresie jego bezpiecznego użytkowania. Wydaje się, że pojęcie zarządcy obiektu budowlanego należy interpretować w sposób szerszy od unormowań zamieszczonych w ustawie o gospodarce nieruchomościami. Taka konieczność wynika z faktu, iż obiekt budowlany może stanowić przedmiot odrębnej nieruchomości, przy czym zazwyczaj jest tak, że stanowi część składową nieruchomości gruntowej. Dlatego pojęciem zarządcy obiektu budowlanego należy objąć każdą osobę (tj. użytkownika, najemcę czy dzierżawcę) władającą obiektem na podstawie zawartego z właścicielem stosunku prawnego, na której spoczywa obowiązek zarządzania tym obiektem ${ }^{18}$. Przywołane w orzecznictwie NSA ${ }^{19}$ przepisy ustawy o gospodarce nieruchomościami mają zatem charakter jedynie pomocniczy i służą do ustalenia zakresu uprawnień, które musi posiadać dany podmiot, aby można mu było przypisać przymiot zarządcy w rozumieniu prawa budowlanego ${ }^{20}$.

Glosowany wyrok NSA uważam za słuszny. Utrzymanie obiektów budowlanych w należytym stanie technicznym jest podstawowym warunkiem zapewnienia ich bezpiecznego użytkowania. Obowiązek utrzymania obiektu budowlanego w należytym stanie technicznym wynika z art. 61 pr. bud. Ciąży on co do zasady na właścicielu lub zarządcy obiektu budowlanego, czyli na podmiotach władnych do rozporządzania obiektami budowlanymi zgodnie z potrzebami wynikającymi z ich przeznaczenia ${ }^{21}$. W szczególności, jak wynika z orzecznictwa, stroną postępowania prowadzonego w trybie art. 66 pr. bud., dotyczącego postępowania w sprawie nieodpowiedniego stanu technicznego i estetycznego obiektu budowlanego oraz wykorzystywania go w sposób zagrażający życiu, zdrowiu ludzi, środowisku lub bezpieczeństwu mienia, jest właściciel lub zarządca obiektu ${ }^{22}$. Niezastosowanie się przez właściciela lub zarządcę obiektu budowlanego do ciążących na nim z mocy

18 S. Serafin, Prawo budowlane. Komentarz, Warszawa 2006, s. 428.

19 Zob. wyrok NSA z dnia 3 lutego 2011 r., II OSK 245/10, LEX nr 992523.

20 S. Zwolak, Strony postępowania w sprawie utrzymania obiektów budowlanych, „Administracja. Teoria - Dydaktyka - Praktyka" 2017, nr 2, s. 89.

21 E. Radziszewski, Prawo budowlane. Przepisy i komentarz, Warszawa 2005, s. 174.

22 Wyrok WSA w Opolu z dnia 17 kwietnia 2012 r., II SA/Op 56/12, LEX nr 1384942; wyrok WSA w Olsztynie z dnia 6 stycznia 2011 r., II SA/O1 553/11, LEX nr 984784. 
prawa obowiązków, mających na celu utrzymanie obiektu we właściwym stanie technicznym i estetycznym, uprawnia właściwy organ do ingerencji zmierzającej do ich wyegzekwowania ${ }^{23}$. W przypadku stwierdzenia, że obiekt budowlany może zagrażać życiu lub zdrowiu ludzi, bezpieczeństwu mienia bądź środowiska, albo jest użytkowany w sposób zagrażający życiu lub zdrowiu ludzi, bezpieczeństwu mienia lub środowiska, albo jest w nieodpowiednim stanie technicznym, albo powoduje swym wyglądem oszpecenie otoczenia, właściwy organ nakazuje w drodze decyzji usunięcie stwierdzonych nieprawidłowości, określając termin wykonania tego obowiązku, wyznaczony z uwzględnieniem rodzaju stwierdzonych nieprawidłowości i stopnia naruszenia przepisów techniczno-budowlanych ${ }^{24}$. W świetle orzeczenia NSA za błędne należy uznać wyznaczenie adresatów decyzji z art. 66 pr. bud., którymi stali się spadkobiercy byłego posiadacza nieruchomości, na której położony jest budynek w złym stanie technicznym. Sama okoliczność spadkobrania po byłym posiadaczu nieruchomości nie czyni bowiem spadkobierców tej osoby posiadaczami nieruchomości oraz zarządcami obiektu budowlanego, gdyż te osoby nigdy faktycznie nie władały nieruchomością oraz nie znajdowały się w rejestrze gruntów i budynków jako osoby władające.

\section{BIBLIOGRAFIA}

Baran B., Prawo cywilne dla zarządców nieruchomości, Warszawa 2012.

Bończak-Kucharczyk E., Zarządzanie nieruchomościami mieszkalnymi. Aspekty prawne i organizacyjne, Warszawa 2011.

Despot-Mładanowicz A., [w:] Prawo budowlane. Komentarz, red. A. Gliniecki, Warszawa 2012.

Jędrzejewski S., Nowe prawo budowlane, Bydgoszcz 1994.

Myczkowski L., Własność budynków i lokali oraz inne prawa rzeczowe w praktyce, Warszawa 2005.

Radziszewski E., Prawo budowlane. Przepisy i komentarz, Warszawa 2005.

Rudnicki S., Własność nieruchomości, Warszawa 2008.

Serafin S., Prawo budowlane. Komentarz, Warszawa 2006.

Śliwiński A., Zarządzanie nieruchomościami. Podstawy wiedzy i praktyki gospodarowania nieruchomościami, Warszawa 2000.

Ustawa z dnia 7 lipca 1994 r. - Prawo budowlane (t.j. Dz.U. 2018, poz. 1202 z późn. zm.).

Ustawa z dnia 21 sierpnia 1997 r. o gospodarce nieruchomościami (t.j. Dz.U. 2018, poz. 2204 z późn. $\mathrm{zm}$.).

Wyrok NSA we Wrocławiu z dnia 14 maja 1996 r., SA/Wr 2096/95, LEX nr 29541.

Wyrok NSA z dnia 3 lutego 2011 r., II OSK 245/10, LEX nr 992523.

Wyrok NSA z dnia 21 marca 2012 r., II OSK 2596/10, LEX nr 1145621.

Wyrok NSA z dnia 12 stycznia 2017 r., II OSK 976/15, LEX nr 2198117.

23 A. Despot-Mładanowicz, [w:] Prawo budowlane. Komentarz, red. A. Gliniecki, Warszawa 2012, s. 591.

${ }^{24}$ Zob. wyrok WSA we Wrocławiu z dnia 28 października 2010 r., II SA/Wr 395/10, LEX nr 755587. 
Pobrane z czasopisma Studia Iuridica Lublinensia http://studiaiuridica.umes.pl Data: 26/04/2023 17:14:00

Glosa do wyroku Naczelnego Sądu Administracyjnego z dnia 2 lipca 2018...

Wyrok WSA w Poznaniu z dnia 23 kwietnia 2008 r., I SA/Po 508/07, LEX nr 505941. Wyrok WSA w Białymstoku z dnia 8 maja 2008 r., II SA/Bk 535/07, LEX nr 510175. Wyrok WSA we Wrocławiu z dnia 28 października 2010 r., II SA/Wr 395/10, LEX nr 755587. Wyrok WSA w Olsztynie z dnia 6 stycznia 2011 r., II SA/Ol 553/11, LEX nr 984784. Wyrok WSA w Gdańsku z dnia 13 stycznia 2011 r., II SA/Gd 733/10 LEX nr 752627. Wyrok WSA w Warszawie z dnia 1 kwietnia 2011 r., VII SA/Wa 2514/10, LEX nr 1128161. Wyrok WSA w Opolu z dnia 17 kwietnia 2012 r., II SA/Op 56/12, LEX nr 1384942. Wyrok WSA we Wrocławiu z dnia 25 lipca 2012 r., II SA/Wr 167/12, LEX nr 1229042. Wyrok WSA w Warszawie z dnia 27 czerwca 2017 r., VII SA/Wa 1895/16, LEX nr 2342718. Zwolak S., Strony postępowania w sprawie utrzymania obiektów budowlanych, „Administracja. Teoria - Dydaktyka - Praktyka” 2017, nr 2.

\section{SUMMARY}

The Supreme Administrative Court in the judgement of 2 July 2018 (II OSK 3285/17, LEX No. 2523637) assumed that the decision ordering the removal of the irregularities found in the construction work may be directed to the administrator of this facility. According to the Supreme Administrative Court, however, a person who has never owned the building and is not disclosed in the land and building register as the ruler can not be considered as the manager of a building object.

Keywords: owner; manager; maintenance and use of a building object 